\section{Frequency and duration of breast- feeding in Cuban children with Type 1 diabetes mellitus (DM)}

\author{
Freqüência e duração do \\ aleitamento materno em crianças \\ cubanas com Diabetes Mellitus Tipo
}

It has been suggested that breast-feeding is a protective factor against Type $1 \mathrm{DM}$ due to anti-infection properties or delay in exposure to other agents in the diet. A descriptive study was carried out using data from the Cuban National Registry of ChildhoodOnset Diabetes Mellitus (CNRDM). The goal of the study was to determine the frequency and duration of breast-feeding in Cuban children with Type 1 DM. Four hundred and eighty-six children were registered in the CNRDM between January 1, 1988, and December 31, 1993. Breast-feeding data was obtained from two hundred and sixty three $(54.1 \%)$ of the total registered children. Of these children, two hundred and one $(76.4 \%)$ were breast-fed. The median duration of breast-feeding was three months (Total range 1-44 months). No statistically significant association was found between the mean age at DM or the clinical profile at diagnosis and the breast-feeding duration groups ( $p>0.05$, respectively). In conclusion, Cuban children with Type 1 DM have relatively low frequency of breastfeeding. When breast-feeding is studied without stratifying for different types of breast-feeding (e.g. exclusive and non-exclusive), there is no association found with the age at DM diagnosis or the clinical profiles at diagnosis.

Keywords: Breast feeding. Diabetes mellitus, insulin-dependent. Children. Cuba

\section{Fernando Collado-Mesa}

Instituto Nacional de Endocrinologia

Zapata y D, Vedado

Ciudad Habana 10400

Cuba

E-mail: inen@infomed.sld.cu
Oscar Díaz-Díaz

Instituto Nacional de Endocrinologia Cuba 


\section{Resumo}

Há evidências de que o aleitamento materno age como um fator protetor contra o DM Tipo 1 devido a propriedades antiinfecciosas ou porque retarda a exposição a outros agentes na dieta. Foi realizado um estudo descritivo com dados do Registro Nacional Cubanas de Diabetes Mellitus na Infância (CNRDM). O objetivo desse estudo era determinar a freqüência e duração do aleitamento materno em crianças cubanas com DM Tipo 1. Quatrocentas e oitenta e seis crianças foram cadastradas no CNRDM entre 1 de janeiro de 1988 e 31 de dezembro de 1993. Os dados sobre aleitamento materno foram obtidos de duzentas e sessenta e três crianças (54.1\%) do total registrado. Dessas crianças, duzentas e uma (76.4\%) foram amamentadas. A duração média do aleitamento materno foi de (3) meses (Variação total entre 1 e 44 meses). Não foi encontrada nenhuma diferença estatisticamente significante entre a idade média de início e os grupos de duração do aleitamento materno ( $p>0.05$ ). Concluindo, as crianças cubanas com DM Tipo 1 apresentam uma freqüência relativamente baixa tanto do aleitamento materno exclusivo como não exclusivo. Quando o aleitamento materno é estudado sem estratificação em diferentes tipos (ex. exclusivo e não exclusivo), não encontra-se associação com a idade ou perfil clínico no momento do diagnóstico.

Palavras-chave: Aleitamento materno. Diabetes mellitus insulino-dependente. Criança. Cuba
The current hypothesis on the etiology of Type 1 Diabetes Mellitus (DM) is that the disease develops in genetically susceptible individuals as an autoimmune disease triggered by certain environmental factors. There is increasing evidence that certain nutrients may play either a protective or provocative role in the development of Type $1 \mathrm{DM}^{1}$. It has been suggested that breastfeeding is a protective factor against Type 1 DM due to anti-infection properties or delays in exposure to other agents in the diet ${ }^{2}$.

A descriptive study was carried out using data from the Cuban National Registry of Childhood-Onset Diabetes Mellitus (CNRDM). The goal of the study was to determine the frequency and duration of breast-feeding in Cuban children with Type $1 \mathrm{DM}$. The CNRDM, created in 1979, is a population-based Registry enrolled as a Participating Center of the World Health Organization (WHO) Multinational Project for Childhood Diabetes (DiaMond Project) since $1990^{3}$. CNRDM's retrospective data on breast-feeding frequency and duration was collected at the diagnosis of DM. However, the data does not take into account whether or not breast-feeding was exclusive or nonexclusive.

Age at diagnosis was presented as a mean \pm SD. Clinical profiles at DM diagnosis were classified into five groups according to severity. The frequency distribution of clinical profiles at diagnosis was presented as a percentage. The Kruskal-Wallis test and Mantel-Haenszel Chi squared test were used for the analysis of the data. $P$ values $<0.05$ were considered statistically significant. All calculations were made using the 6.03 version of the Epi-info program.

Four hundred and eighty-six children were registered in the CNRDM between January 1, 1988, and December 31, 1993. Breast-feeding data was obtained from two hundred and sixty three $(54.1 \%)$ of the total registered children. Of these children, two hundred and one (76.4\%) were breast-fed. The median duration of breast-feeding was three (3) months (Total range $1-44$ months). 
In assessing the possibility that children with a shorter duration of breast-feeding could have had an earlier onset of the disease, information on the breast-feeding status and duration was separated into three (3) groups. Of all the children enrolled, sixty four $(24.3 \%)$ were not breast-fed, seventy one of them (27.0\%) were breast-fed for 1-2 months, and one hundred and twenty eight (48.7\%) were breast-fed for 3-44 months. No statistically significant association was found between the mean age at onset and the breast-feeding duration groups (p>0.05); (Table 1).

The potential effect of the duration of breast-feeding on the type of clinical profile at DM diagnosis was also examined. No statistically significant association was found between the clinical profile at diagnosis and the breast-feeding duration groups ( $p>0.05$ ); (Table 1 ).

As far as the authors are aware, this is the first report on the frequency of breastfeeding in Cuban children with Type 1 DM. The fact that information on breast-feeding was available only in $54.1 \%$ of the total registered children during the studied period constitutes a limitation on the study's results. However, lack of information on breast-feeding was neither associated to age at diagnosis nor to clinical profile at diagnosis (data not presented).

The proportion of Cuban children with Type 1 DM who were breast-fed during 3 or more months was similar to that in the Cuban general population $(48.7 \%$ vs. $45.2 \%)^{4}$. These results suggest no important differences in exposure to breast-feeding practices. Cuban children with Type $1 \mathrm{DM}$ represent a very small proportion of the Cuban infant population ${ }^{5}$. Thus, a different genetic susceptibility to Type 1 DM or a different exposure to factors other than nonexclusive breast-feeding could be the reason for the similar breast-feeding rates.

The Cuban population is primarily a mixture of persons of Spanish and African descent. The frequency of some genetic markers for predisposition to Type $1 \mathrm{DM}$ (HLA-DR3 or HLA-DR4 alleles) in the Cuban general population is lower than that reported in populations with a much higher incidence of Childhood-Onset Type $1 \mathrm{DM}^{6}$. However, the different frequency of these markers does not fully account for the large difference in Type $1 \mathrm{DM}$ incidence between populations ${ }^{5}$.

It would be expected that such differences could be partially explained by different levels of exposure to environmental factors that may play either a protective (i.e. breast-feeding) or provocative role in the development of Type 1 DM. However, a similar prevalence of breast-feeding (exclusive or non-exclusive) has been reported in populations with a large difference in Type 1 DM incidence, for example, Cuba and Sweden ${ }^{4,7}$.

Table 1 - Breast-feeding duration for Cuban children with Type 1 DM, according to Age Group and Clinical profile at DM diagnosis.

\begin{tabular}{lccc}
\hline & \multicolumn{3}{c}{ Breast-feeding Status/Duration } \\
& Not breast-fed & $1-2$ months & $3-44$ months \\
\hline Age in years & $8.5 \pm 3.5$ & $8.2 \pm 3.8$ & $8.4 \pm 3.6$ \\
mean \pm SD & & & \\
Clinical profile & & & \\
$\mathrm{n}(\%)$ & & & \\
$\quad$ Non-symptomatic & $3(4.7)$ & $1(1.4)$ & $2(1.6)$ \\
$\quad$ General symptoms & $25(39.0)$ & $26(36.6)$ & $52(40.6)$ \\
Ketosis & $14(21.9)$ & $17(23.9)$ & $25(19.5)$ \\
$\quad$ Mild DKA & $17(26.6)$ & $19(26.8)$ & $38(29.7)$ \\
$\quad$ Severe DKA & $5(7.8)$ & $8(11.3)$ & $11(8.6)$ \\
\hline
\end{tabular}


Apart from the different genetic susceptibility, this contradictory non-standardized data may be explained by the fact that the suggested protective role that breast-feeding may play in Type 1 DM could take place only when breast-feeding is exclusive.

In conclusion, Cuban children with Type 1 DM demonstrate a relatively low frequency of both exclusive and non-exclusive breast-feeding. This low frequency is similar to that of the Cuban general population. Current Public Health policy has encouraged an increase in exclusive breast-feeding in Cuba. When breast-feeding is studied without stratifying for different types of breast-feeding (e.g. exclusive and non-exclusive), there is no association found with the age at DM diagnosis or the clinical profiles at diagnosis. Prospective studies are needed and should include a detailed characterization of exposure to breast-feeding and early introduction of nutrients (e.g. Cow's milk) in children with Type $1 \mathrm{DM}$ and in healthy children from different countries.

\section{Acknowledgments}

The authors are grateful to Pediatric Endocrinologists in Cuba for their help in collecting the data.

\section{References}

1. Kostraba JN. What can epidemiology tell us about the role of infant diet in the etiology of diabetes? Diabetes Care 1994; 17: 87-91.

2. Borch-Johnsen K, Mandrup-Poulsen T, ZachauChristiansen B, Joner G, Christy M, Kastrup K. Relation between breast-feeding and incidence rates of insulindependent diabetes mellitus: a hypothesis. Lancet 1984; 2: 1083-6.

3. WHO Diamond Project Group. WHO Multinational Project for Childhood Diabetes. Diabetes Care 1990; 13: 1062-8.

4. Amador M. Feeding practices and growth in a healthy population of Cuban infants. Food Nutr Bull 1992; 108-14.
5. Karvonen M, Tuomilehto J, Libman I, LaPorte R. A review of the recent epidemiological data on the worldwide incidence of type I (insulin-dependent) diabetes mellitus. Diabetologia 1993; 36: 883-926.

6. Cabrera-Rode E, Licea ME, Molina G, Arranz C, DíazHorta O, Uriarte A. Immunogenetic, clinical and metabolic characterization of non-insulin dependent diabetes mellitus according to the presence of anti-islet cell antibodies. Avances en Diabetología 1995; 10: 1101 105.

7. Blom L, Dahlquist G, Nystrom L, Sandstrom A, Wall S. The Swedish childhood diabetes study- social and perinatal determinants for diabetes in childhood. Diabetologia 1989; 32:7-13. 